\title{
BIOLOGICAL PROJECTILES (PHAGE, YEAST, BACTERIA) FOR GENETIC TRANSFORMATION OF PLANTS
}

\author{
JULIE R. KIKKERT, ${ }^{1}$ GERARD A. HUMISTON, ${ }^{2}$ MIHIR K. ROY, ${ }^{3}$ AND JOHN C. SANFORD \\ Department of Horticultural Sciences. Cornell University, New York State Agricultural Experiment Station, Geneva, New York 14456
}

(Received 21 January 1998; accepted 2 October 1998; editor J. J. Finer)

\begin{abstract}
SUMMARY
Bacteriophage lambda particles, yeast cells, and bacterial cells were tested as projectiles to deliver marker/reporter genes into plant cells via the biolistic process. When phage particles were complexed to tungsten or gold particles and used to bombard tobacco cells, fewer than 15 cell clusters per plate transiently expressed $\beta$-glucuronidase (GUS). Cells of wildtype Saccharomyces cerevisiae were too large to be effective projectiles, but use of a reduced-size mutant resulted in a small number of transformants. Escherichia coli cells complexed with tungsten were the most effective projectile for plant transformation. Various methods to prepare $E$. coli were tested to reduce particle size, improve binding of bacteria to metal particles, and/or minimize particle clumping. In maize, the number of transformants was highest when bacteria/tungsten particles were air-dried onto macrocarriers from an aqueous solution. When maize cells were bombarded with bacteria/ tungsten projectiles, rates of transient gene expression ( 2000 per plate) and stable transformation ( 50 per plate) were only two- to threefold lower than when purified DNA was used. Transformation of tobacco with $E$. coli projectiles was improved when the bacteria were treated with a series of ethanol and ether washes, then dried into a powder. Nevertheless, tobacco transformation was still 24- (transient) and 200-fold (stable) less than when purified DNA was used. Biological projectiles can be effective for plant transformation and are advantageous because once a DNA construct is made and put into the appropriate microorganism, the need to isolate and purify DNA for the biolistic process is eliminated, which saves time and lessens DNA shear. Such projectiles may be especially well suited where high molecular weight DNA constructs are needed.
\end{abstract}

Key words: biolistic; microprojectile bombardment; particle bombardment; bacteriophage lambda; Saccharomyces cerevisiae; Escherichia coli.

\section{INTRODUCTION}

Biolistics has been used to deliver DNA into cells of plants, animals, yeast, fungi, and bacteria (Sanford et al., 1993). In the standard procedure, purified DNA is precipitated onto micron-size tungsten or gold particles. The particles are propelled at high velocity toward the recipient cells by a biolistic device.

Rasmussen et al. (1994) first reported biolistic transformation of plant cells using intact bacteria as projectiles. Small plasmids contained within the bacteria were transferred into plant cells, and thus plasmid isolation and purification were not needed. The bacterial projectiles were easy to prepare and their use avoided shear of DNA during plasmid isolation, purification, and binding to tungsten. DNA shear is a special concern when large DNA constructs are used. Rasmussen et al. (1994) used Escherichia coli and Agrobacterium tumefaciens cells that contained plant reporter/marker genes to bombard tobacco and maize suspension cultures. Transformation rates were improved when bacteria were treated for $1 \mathrm{~h}$ with $1 \%$ phenol in Tris-EDTA (TE) buffer and then mixed with tungsten particles.

${ }^{1}$ To whom correspondence should be addressed.

${ }^{2}$ Present address: Sanford Scientific, 877 Marshall Road, Waterloo, New York 13165

${ }^{3}$ Present address: Garst Seeds, Box 500, Slater, lowa 50244.
After bombardment of tobacco, hundreds of cells per plate transiently expressed $\beta$-glucuronidase (GUS), but no kanamycin-resistant $\left(\mathrm{Km}^{\mathrm{r}}\right)$ calli were recovered. Transformation rates were higher with maize cell suspensions, where thousands of cells per plate transiently expressed either GUS or anthocyanin reporter genes, and an average of six phosphinothricin (PPT)-resistant calli per plate were recovered.

Other types of biological particles could be effective for biolistic delivery of DNA or other substances into cells. Of particular interest are phage particles and yeast cells which could carry large DNA constructs (phage genomes or yeast artificial chromosomes) into cells. In the present study, the use of bacteriophage $\lambda$ and Saccharomyces cerevisiae projectiles to deliver small DNA constructs into plant cells was examined. Additionally, the biolistic use of $E$. coli projectiles was optimized and improved rates of transformation were obtained.

\section{Materials AND METHODS}

Phage. Bacteriophage $\lambda \mathrm{gt} 22$ (Han and Rutter, 1987) with the plant gene cassette from pBI426 (Table 1) was obtained from J. L. Rasmussen, SUNY, Plattsburgh, NY. Phage particles were multiplied in E. coli strain LE392 (Promega Corp., Madison, WI), and purified on a CsCl gradient as described by Sambrook et al. (1989). DNA was isolated and purified from a portion of the phage particles, also according to Sambrook et al. (1989).

For bombardment of plant cells, we complexed phage particles with either M-10 tungsten (1 $\mu \mathrm{m}$ diameter) (Sylvania Chemicals, GTE Products Corp.. 
TABLE 1

EFFECT OF DIFFERENT PLASMID CONSTRUCTS ON TRANSIENT GUS EXPRESSION AND STABLE TRANSFORMATION WHEN CSCLPURIFIED DNA WAS COMPLEXED WITH TUNGSTEN M-10 PARTICLES AND BOMBARDED INTO MAIZE BMS CELLS

\begin{tabular}{|c|c|c|c|}
\hline Plasmid & Plant genes and promoters & $\begin{array}{l}\text { No. GUS-positive } \\
\left.\text { spots (transient }{ }^{2}\right)\end{array}$ & $\begin{array}{l}\text { No. PPT } \\
\text { colonies }\end{array}$ \\
\hline $\mathrm{pUC11} 8^{\mathrm{b}}$ & none & $0 \mathrm{z}$ & $\mathrm{O}_{\mathrm{z}}$ \\
\hline $\mathrm{pBI} 426^{\mathrm{c}}$ & 35S-35S-AMV-uidA/nptII & $305 y$ & $0 \mathrm{z}$ \\
\hline pBARGUS $^{d}$ & $\begin{array}{l}\text { 35S-Adh intron-bar } \\
\text { Adh-Adh intron-uidA }\end{array}$ & $835 x$ & $39 y$ \\
\hline $\mathrm{pDM}^{\mathrm{D} 43^{\mathrm{e}}}$ & Actin-bar/uidA & $1,486 \mathrm{w}$ & $36 y$ \\
\hline pSAN18 & 35S-35S-bar/uidA & $4,036 \mathrm{v}$ & $52 \mathrm{y}$ \\
\hline
\end{tabular}

${ }^{a}$ Values represent the mean number per bombarded plate; five replicate plates for transient GUS expression and seven replicate plates for PPT ${ }^{r}$ calli. Means within each column that are followed by the same letter are not significantly different as determined by a least significant difference test at the $5 \%$ level.

'Vieira and Messing.(1987).

'From William L. Crosby, Plant Biotechnology Institute, NRC Canada, Saskatoon, Saskatchewan

dFromm et al. (1990).

'From David McElroy, Plant Gene Expression Center, Albany, CA.

From Alan D. Blowers, Sanford Scientific, Waterloo, NY.

Towanda, PA) or gold particles (l $\mu \mathrm{m}$ diameter, BioRad, Hercules, CA) by combining the following components: $50 \mu \mathrm{l}$ of tungsten or gold particles at $60 \mathrm{mg} / \mathrm{ml}$ in $50 \%$ glycerol, $5 \mu \mathrm{l}$ phage particles at $1 \times 10^{10}$ plaque-forming units per ml, $1.3 \mu \mathrm{l}$ of $1 \mathrm{M} \mathrm{MgSO}_{4}, 2.5 \mu \mathrm{l}$ of $\mathrm{pUCl} 18$ carrier DNA at $1 \mu \mathrm{g} /$ $\mu \mathrm{l}, 50 \mu \mathrm{l}$ of $2.5 \mathrm{M} \mathrm{CaCl}_{2}$, and $20 \mu \mathrm{l}$ of $0.1 \mathrm{M}$ spermidine-free base. The reaction mixture was handled according to standard microcarrier preparation techniques (Kikkert, 1993) and was sufficient for six shots with the biolistic device.

Yeast. Two strains of Saccharomyces cerevisiae were tested. Cells of strain 948 are approximately $6 \mu \mathrm{m}$ in diameter when cultured in a rich glucose medium (Armaleo et al., 1990). 'Wee' strain BF350-13c (B. Futcher, Cold Spring Harbor, NY), contains the CLN3-l gene (also called WHI1 and DAF1), a dominant mutation that causes small cell size (Sudbery et al., 1980; Tyers et al., 1992). The diameter of BF350-13c is approximately $3.3 \mu \mathrm{m}$ when grown on glucose medium and $2.8 \mu \mathrm{m}$ when grown on glycerol-containing medium (B. Futcher, personal communication). Both yeast strains were transformed with YEp352 (Hill et al., 1986) into which the plant gene cassette from pBI426 (Table 1) had been cloned (obtained from A. D. Blowers, Sanford Scientific, Waterloo, NY). Yeast transformation was by particle bombardment as described by Armaleo et al. (1990) and Klein et al. (1991).

Yeast cells were grown to mid- or late-log phase in Uracil Drop Out medium (Klein et al.. 1991) with $2 \%$ (wt/vol) glucose as the carbon source. Two methods to dehydrate and shrink the yeast before bombardment were tested. In the first method, cells were consecutively washed in 70\% EtOH, 95\% EtOH, $100 \% \mathrm{EtOH}$, and diethyl ether. The ether was allowed to evaporate and the remaining powder of dried cells was collected. In the second procedure, cells were washed in $70 \% \mathrm{EtOH}$ and then diethyl ether. The ether was decanted off and the yeast pellet was resuspended in $100 \% \mathrm{EtOH}$ and stored at $-20^{\circ}$ C. In either case, the pellets were broken up with a glass rod. The yeast cells were suspended in $100 \% \mathrm{EtOH}$ and aliquots were placed onto the macrocarriers. Dehydrated cells were prepared with and without tungsten M-5 or M-10 particles added in the final suspension. In some experiments, live yeast cells mixed with tungsten particles were used. The following chemical treatments of nondehydrated yeast were also tested: a) $1 \%$ sodium dodecyl sulfate for $5 \mathrm{~min}$, b) 2 drops of chloroform added to $2 \mathrm{ml}$ of cells for $5 \mathrm{~min}$, c) $1 \%$ phenol for $5 \mathrm{~min}$, d) $0.1 \mathrm{M} \mathrm{LiCl}$ in TE buffer in the final yeast suspension, or e) $50 \mu \mathrm{g}$ nystatin (Sigma Chemical Co., St. Louis, MO; \#N9767) per ml in the final yeast suspension. For nearly all yeast experiments, each macrocarrier was loaded with the equivalent of $10 \mu \mathrm{l}$ of yeast cells at an $\mathrm{OD}_{\text {tixy }}$ of 10.0 (measured using a 1:100 diluted sample). In one experiment, yeast cells were further concentrated to an $\mathrm{OD}_{600}$ of 20 or 50 . In another test, the distance between the target plant cells and the launch point of the yeast projectiles was reduced from the standard $12 \mathrm{~cm}$ to either 5 or $8 \mathrm{~cm}$.

Bacteria. Two strains of Escherichia coli were used, DH5 $\alpha \mathrm{F}^{\prime}$ and DHlob (GIBCO BRL, Grand Island, NY). Bacteria were transformed with the plasmids listed in Table 1 by standard electroporation techniques. Bacteria were grown to mid-log phase $\left(O D_{600}=0.5\right)$ in Luria broth $(\mathrm{LB})$ and treated with chloramphenicol as described by Rasmussen et al. (1994). The cells were concentrated by centrifugation at $10410 \times \mathrm{g}$ and $4^{\circ} \mathrm{C}$ for $15 \mathrm{~min}$, followed by resuspension of the pellet with fresh LB to an optical density of 10.0 at $600 \mathrm{~nm}$.

Six different methods were used to prepare bacterial cells for use as projectiles.

1. Aqueous-dry method. This method was previously described by Rasmussen et al. (1994). Brieffy, a $160-\mu l$ aliquot of bacteria $\left(O D_{600}=10\right)$ was suspended in TE buffer, treated with $1 \%$ phenol for $1 \mathrm{~h}$, pelleted, resuspended in $70 \mu \mathrm{TE}$ buffer, and mixed with $3 \mathrm{mg}$ of M-10 particles. A 10- $\mu \mathrm{l}$ aliquot of the bacteria/tungsten mixture was pipetted onto each macrocarrier. The macrocarriers were placed in a desiccator where the solution of projectiles dried naturally. For comparison, each macrocarrier contained approximately $0.4 \mathrm{mg}$ of tungsten, and the equivalent of $23 \mu \mathrm{l}$ of bacteria at $O D_{600}$ $=10$. In this study, we also tested different concentrations of bacteria mixed with the tungsten particles, and treatment of the tungsten particles with different concentrations of pUC118 carrier DNA (Kikkert, 1993) before being mixed with the bacteria.

2. Ether-dry method. A $700-\mu \mathrm{l}$ aliquot of bacteria at $0 \mathrm{D}_{600}=10.0$ was placed into a 1.5-ml microcentrifuge tube of known weight. The bacteria were centrifuged at $13000 \times \mathrm{g}$ for $1 \mathrm{~min}$, resuspended with $1 \mathrm{ml}$ sterile TE buffer

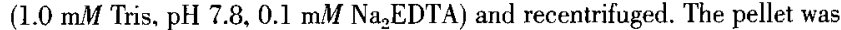
resuspended with $1 \mathrm{ml}$ of $1 \%$ phenol in TE buffer and incubated for $1 \mathrm{~h}$ at room temperature. Bacteria were pelleted and washed with $1 \mathrm{ml} \mathrm{TE}$ buffer (without phenol). After another centrifugation, the bacteria were resuspended with $1 \mathrm{ml}$ of a $10 \mathrm{mg} / \mathrm{ml}$ suspension of $\mathrm{M}-10$ particles in $70 \% \mathrm{EtOH}$ and incubated for $5 \mathrm{~min}$. Bacteria were successively pelleted and washed with 1 $\mathrm{ml}$ 95\% EtOH, $1 \mathrm{ml} \mathrm{100 \%} \mathrm{EtOH}$, and $300 \mu \mathrm{l}$ diethyl ether. Cells were incubated for $5 \mathrm{~min}$ in each of the wash solutions. After the final centrifugation, the ether was discarded and the pellets were left to dry in a fume hood. The dry particles were weighed and resuspended in $150 \mu \mathrm{l}$ of absolute EtOH per $10 \mathrm{mg}$ of particles. The tube was placed in a water bath sonicator (Branson 1200, Branson Ultrasonic Corp., Danbury, CT) for 5 sec to aid in particle resuspension. A 6- $\mu$ l aliquot of particles was pipetted onto each macrocarrier, which was then placed in a desiccator to dry. For comparison, each macrocarrier contained approximately $0.4 \mathrm{mg}$ of tungsten and the equivalent of $28 \mu \mathrm{l}$ of bacteria at $O D_{600}=10$. Many parameters were tested in order to optimize transformation. These are described in detail in the text and figures and include the concentration of tungsten added to the bacteria, the solution used to resuspend the final powder, sonication of the final suspension, different quantities of bacteria/tungsten loaded onto the macrocarrier, the addition of carrier DNA, and helium flush of the bombardment chamber. Furthermore, we tested the addition of the polycationic polymers chitosan, poly-L-lysine, and lysozyme to the bacteria/tungsten mixtures to improve adhesion, as described by Goldberg et al. (1990).

3. $37^{\circ} \mathrm{C}$-Dry method. Bacteria were washed once with TE buffer and then twice with sterile water. Tungsten particles $(0.25 \mathrm{~g}$ per $125 \mathrm{ml}$ bacteria at $O D=10$ ) were added to the last water wash. The tube with the pellet of bacteria and tungsten was placed in a jar with Drierite desiccant and incubated at $37^{\circ} \mathrm{C}$ for $16 \mathrm{~h}$. The dry pellet was ground into a fine powder with a glass test tube and stirring rod. Aliquots of 2.5 or $5.0 \mathrm{mg}$ of the powder were resuspended in $75 \mu \mathrm{l}$ of absolute EtOH. The suspension was incubated for 5 min, vortexed briefly, and sonicated for 5 sec in the waterbath sonicator. Macrocarriers were loaded with $6 \mu \mathrm{l}$ of the suspension and were placed in a desiccator to dry.

4. Spray-drying. Bacteria were grown to stationary phase in LB medium and treated with $1 \%$ phenol in TE buffer for $1 \mathrm{~h}$. The bacteria were pelleted and then resuspended in distilled water to an $\mathrm{OD}_{\text {tow }}$ of 5.0. Tungsten M-5 particles (mean diameter of $0.5 \mu \mathrm{m}$ ) were mixed with bacteria $(1 \mathrm{~g}$ per 100 ml) and processed through a Yamato Pulvis GB-21 Mini-Spray Dry apparatus. The heater was set at $150^{\circ} \mathrm{C}$ which corresponds to $200^{\circ} \mathrm{C}$ at the inlet and $100^{\circ} \mathrm{C}$ at the outlet. The powder was resuspended in $48 \mu \mathrm{l}$ of $100 \% \mathrm{EtOH}$ per $3 \mathrm{mg}$ of particles. A 10- $\mu \mathrm{l}$ aliquot was loaded onto each macrocarrier.

5. Gold electroplating. A $160-\mu$ l aliquot of bacteria $\left(O D_{6 \notin\}}=10\right)$ was placed into a $1.5-\mathrm{ml}$ microcentrifuge tube. The bacteria were washed twice with distilled water, pelleted, and resuspended in $500 \mu \mathrm{l}$ of $132 \mathrm{mM} \mathrm{AuCl}$ 
We dipped the tube into a waterbath sonicator twice for 15 sec each to break up clumps of bacteria. Two strips of 0.1 -mm-diameter gold wire (Johnson Matthey, Materials Technology, U.K.), about $5 \mathrm{~cm}$ long, were placed on opposite sides of the microcentrifuge tube. The two gold wires were then attached to electrodes and a current was passed between them. The polarity of the current was reversed every $15 \mathrm{sec}$ at which time the suspension was also mixed with a pipette. The cells were treated for $4 \mathrm{~h}$ during which time a brown precipitate formed. The tube was centrifuged for $5 \mathrm{~min}$ at $13000 \times \mathrm{g}$. The pellet was washed with $70 \%$ and $95 \% \mathrm{EtOH}$ and was finally suspended in $100 \mu \mathrm{l} 95 \% \mathrm{EtOH}$. Macrocarriers were loaded with $6 \mu \mathrm{l}$ of the suspension, then placed in a desiccator to dry.

6. Gold sputtercoating. Macrocarriers that contained bacteria prepared by the aqueous-dry method were coated with gold to a thickness of 50 or 100 angstroms in a Balzers SCD40 Sputter Coater (Balzers, Hudson, NH). Macrocarriers were used directly for bombardment.

Scanning electron microscopy. Macrocarriers that contained bacteria prepared by one of the above methods were cut into small sections with a razor blade. The sections were mounted on a specimen stub with double stick tape. Samples were sputter-coated with gold and observed with a Hitachi S-530 Scanning Electron Microscope.

Plant cells. Maintenance of Nicotiana tabacum L. line NTl suspension cells was as described previously (Russell et al., 1992). Zea mays L. cv. BMS suspension cells were cultured as described by Fromm et al. (1987). Petunia hybrida suspension line 3688 (Pruitt and Hanson, 1991) was obtained from R. Spivey (Comell University, Ithaca, NY) and rice suspension (Oryza sativa L. 'Nippobare') was obtained from J. Cao (Cornell University, Ithaca, NY) (Cao et al., 1991). In vitro-grown Petunia hybrida V26 plants were obtained from J. VanEck, Sanford Scientific, Waterloo, NY.

All suspension-cultured cells were prepared for bombardment as described by Russell et al. (1992). Briefly, 4-d-old cultures were collected on 70-mm filter paper discs (Whatman no. 2), and the discs were placed on bombardment medium containing $1.25 \mathrm{M}$ each of mannitol and sorbitol. The cells were left at room temperature for $1 \mathrm{~h}$ before bombardment to allow the osmoticum to exert its effect on the cells.

Petunia leaves were placed adaxial side up on a semisolid medium, 5 whole leaves per plate arranged in a doughnut pattern. A screen (1.5-mm openings) was used to hold tissue in place during bombardment. Each plate was bombarded twice. After bombardment, leaves were turned over so that the bombarded surface was in contact with the medium.

Biolistic transformation. Plant cells were transformed with a helium-driven biolistic device (Sanford et al., 1991). Unless otherwise noted, the bombardment parameters were $1000 \mathrm{psi}$ helium, $1.0 \mathrm{~cm}$ rupture disc to macrocarrier distance, $1.0 \mathrm{~cm}$ macrocarrier flight distance, and $12 \mathrm{~cm}$ target cell distance. When phage, yeast, or bacteria were used as projectiles, we flushed the sample chamber with helium for $10 \mathrm{sec}$ before pulling a vacuum, in order to reduce drag on the microcarriers. When purified DNA was used, it was complexed with M-10 tungsten particles as described by Kikkert (1993).

Transient GUS expression was assayed $2 \mathrm{~d}$ after bombardment. The cells were incubated with $x$-gluc (5-bromo-3-chloro-2-indolyl- $\beta$-D-glucuronic acid) stain solution (McCabe et al, 1988) at $37^{\circ} \mathrm{C}$ for $24 \mathrm{~h}$. The resultant GUSpositive sectors (blue spots) were counted with the aid of a dissecting microscope. For stable selection, suspension-cultured cells were transferred $24 \mathrm{~h}$ postbombardment to media without mannitol/sorbitol and then $48 \mathrm{~h}$ postbombardment to media with $350 \mathrm{mg}$ kanamycin per 1 or $5-10 \mathrm{mg}$ phosphinothricin (PPT) per l as detailed by Russell et al. (1992). Petunia leaves were transferred $48 \mathrm{~h}$ postbombardment to a medium containing $100 \mathrm{mg}$ kanamycin per l. Differences in the rates of transient GUS expression or stable transformation (Km $\mathrm{Km}^{\mathrm{r}}$ or PPT $\mathrm{r}$ calli) were analyzed by Student's $t$-test or the method of least significant difference, calculated with the aid of Minitab statistical software v. 8.1 (Minitab, Inc., State College, PA).

\section{REsults}

Phage particles. When tobacco cells were bombarded with phage/ tungsten particles, fewer than 15 cells per bombarded plate transiently expressed GUS. In comparison, there were roughly 600 blue spots per plate after bombardment with purified phage DNA, and more than 5000 blue spots per plate when purified pBI426 was used. When maize cells were bombarded with phage particle/tungsten mixtures, there were no GUS-expressing cells.
As an indication of how well phage particles bind to tungsten, the supernatant from the first centrifugation and the pellet from the final centrifugation of the reaction mix were sampled for the presence of viable phage particles. The samples were mixed with $E$. coli cells, spread on agar medium in petri plates, and rated on their ability to form plaques. No plaques formed from any of the test samples. Each component of the reaction was then tested for its effect on phage viability. Calcium chloride, spermidine, and tungsten all reduced phage viability (data not shown), whereas $\mathrm{MgSO}_{4}$ and gold did not. The high $\mathrm{pH}$ of the reaction mixture (10.19) is one possible cause of the reduced phage viability (Amin et al., 1988). Alkalinity of the solution is in large part due to the spermidine stock which has a $\mathrm{pH}$ of 11.64. The negative effect of spermidine on phage viability could be overcome when $6 \mu$ of a $1 M$ Tris [Tris(hydroxymethyl)aminomethane] solution ( $\mathrm{pH} 7.5)$ was added to the reaction or when $\mathrm{MgCl}_{2}$ or $\mathrm{MgSO}_{4}$ were used instead of $\mathrm{CaCl}_{2}$. It is not known whether viability of the phage is important for plant transformation. The plaque assays are simply a tool to determine the number of phage particles present in the solution.

Phage and gold particles by themselves did not adhere well to each other, because after centrifugation the supernatant contained mostly phage and the pellet contained mostly gold particles (determined by plaque assays). Binding appeared to improve when pUC118 DNA, $\mathrm{MgCl}_{2}$, and spermidine were added to the solution, because in this case, equal numbers of phage plaques formed from the supernatant and the pellet samples. When Tris was added to the mixture, more phage plaques formed from the supernatant than from the pellet. Tobacco NTl cells were bombarded with phage/gold particles prepared under the best particle binding conditions, but there were fewer than 10 cell clusters per plate that transiently expressed GUS. Because the rate of transient gene expression in tobacco and maize was so low, phage were not tested for stable transformation or for transformation of other plant species or tissues.

Yeast cells. Transient GUS expression was not detected when yeast strain 948, prepared as a dried powder, was bombarded into tobacco NTl cells, either with or without tungsten particles in the mixture. In contrast, when purified DNA (YEp352 + pBI426 or pBI426) was used, thousands of blue cells per plate were observed. To determine if the yeast penetrated the plant cells, we stained the yeast with $0.1 \%$ (wt/vol) calcofluor white before bombardment of tobacco cells. With fluorescence microscopy, yeast cells were not observed within intact plant cells.

A smaller-size yeast strain (BF350-13c) was tested. Transient GUS expression was not observed when tobacco cells were bombarded with BF350-13c cells prepared by either dehydration method. When live cells were mixed with tungsten particles and bombarded into tobacco, an average of two blue spots per plate was observed, but no kanamycin resistant calli were recovered. Transient GUS expression was not obtained from maize cells bombarded with any yeast preparation. The number of cells that transiently expressed GUS remained low despite altering bombardment conditions such as target distance and density of the yeast on the macrocarrier, or various chemical treatments of the cells as described in Materials and Methods.

Bacteria ( $E$. coli). Aqueous-dry method. Initially, we set out to optimize the aqueous-dry preparation described by Rasmussen et al. (1994). E. coli strains DH5 $\alpha \mathrm{F}^{\prime}$ and DH10b were equally effective projectiles (data not shown) and were used interchangeably in these experiments. The plasmid pBI426 used by Rasmussen is expressed 
TABLE 2

RATES OF TRANSFORMATION IN MAIZE BMS CELLS AFTER BOMBARDMENT WITH PSAN18 IN THE FORM OF CSCL PURIFIED DNA OR AQUEOUS-DRIED E. COLITTUNGSTEN PROJECTILES

\begin{tabular}{lccc}
\hline \multicolumn{1}{c}{ Projectile } & $\begin{array}{c}\text { No. GUS- } \\
\text { positive spotsa }\end{array}$ & NO. PPT CALLI $^{\text {n }}$ & $\begin{array}{c}\text { \% Conversion } \\
\text { transient to stable }\end{array}$ \\
\hline CsCl-purified DNA & $5384 \mathrm{z}$ & $70 \mathrm{z}$ & 1.3 \\
E. coli/tungsten & $1387 \mathrm{y}$ & $33 \mathrm{y}$ & 2.4 \\
& & -fold difference & \\
& 3.9 & 2.1 & -
\end{tabular}

Values represent the mean number per bombarded plate; 10 replicate plates for GUS expression and 5 to 7 replicate plates for PPT ${ }^{\mathrm{r}}$ calli. Means within each column that are followed by the same letter are not significantly different as determined by Student's $t$-test at $P=0.05$.

strongly in tobacco but not in maize BMS cells. Of the plasmids tested, pSAN18 gave the highest rates of GUS expression along with good recovery of PPT calli (Table 1). Thus, it was used in all subsequent maize transformation experiments in this study. Transient GUS expression and recovery of PPT ${ }^{\mathrm{r}}$ calli from maize cells bombarded with $E$. coli projectiles that harbored pSAN18 was also high, and was only two- to fourfold less than when purified pSAN18 was used (Table 2).

The distance of the target cells from the launch point of the microcarriers was varied to determine if shorter distances, which give a harder blast, would improve bacterial penetration into plant cells. At $5 \mathrm{~cm}, 79 \pm 14$ (SE) blue spots per plate were observed with tobacco, compared to $254 \pm 59$ at $8 \mathrm{~cm}$ and $190 \pm 46$ at $12 \mathrm{~cm}$. Although the highest number of GUS-expressing cell clusters was at the 8-cm distance and this was significantly higher than at $5 \mathrm{~cm}$, neither was significantly different than obtained at the $12-\mathrm{cm}$ distance (least significant difference at the $5 \%$ level). Thus, the shorter distances did not improve DNA delivery.

The concentration of bacteria mixed with the M-10 particles had a strong effect on transformation (Fig. 1). However, the concentration that gave the highest rates $\left(O D_{600}=10\right)$ was the one used by Rasmussen et al. (1994). Carrier DNA added to the tungsten before mixing with bacterial cells improved transformation slightly in aqueous-dried bacteria only (Fig. 2).

To understand how to make bacteria into more effective projectiles, we examined bacterial preparations with a scanning electron microscope. The aqueous-dry bacteria form a thick mat on the macrocarrier (Fig. $3 a, b$ ). This is very different from the smaller, more dispersed clumps of particles when purified DNA is used (Fig. $3 f$ ). Thus, alternative methods to prepare bacterial projectiles were evaluated.

Ether-dry method. The particle distribution of ether-dried bacteria (Fig. 3 c) was similar to that obtained with purified DNA/tungsten (Fig. $3 \mathrm{f}$ ). Both the concentration of tungsten added to the bacteria and the solution used to resuspend the final powder affected transformation (Fig. 4). The tungsten particles resuspended better in ethanol, whereas bacteria resuspended better in aqueous solutions. Mixtures of $\mathrm{EtOH}$ and water were also tested, but particle distribution (Fig. $3 c$ ) and transformation rates were highest (data not shown) with $100 \% \mathrm{EtOH}$, especially when the particle suspension was placed in a waterbath sonicator just before the macrocarriers were loaded. In tobacco, there were 778 blue cells per plate without sonication and 1345 with sonication $(P=0.01)$. The quantity of bacteria/tungsten

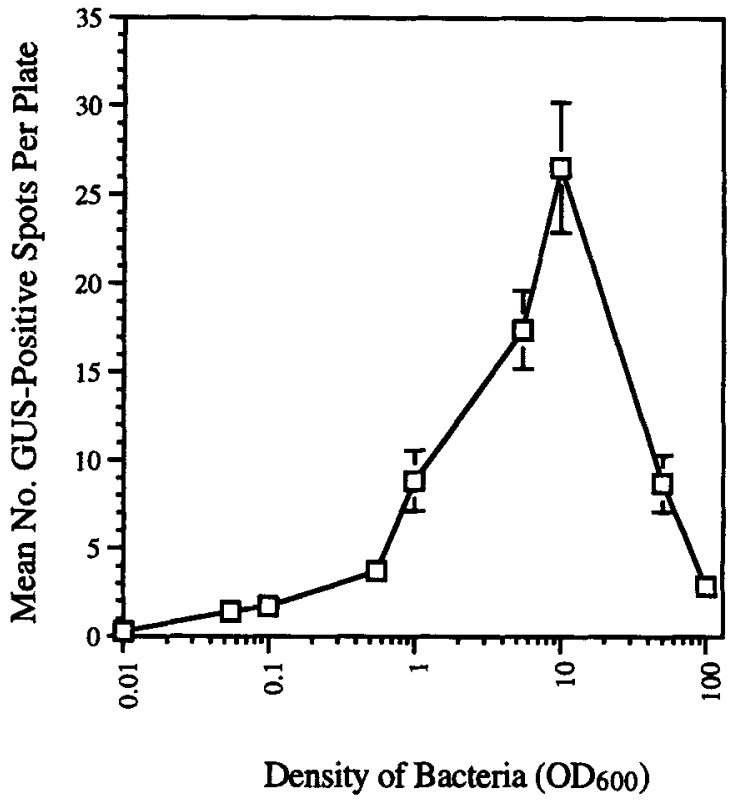

FIG. 1. Effect of bacterial concentration in the aqueous-dry method. Bacteria were diluted to different $O D_{600}$ values, mixed with $50 \mu \mathrm{l}$ of $\mathrm{M}-10$ particles, and used to bombard tobacco NTI cells.

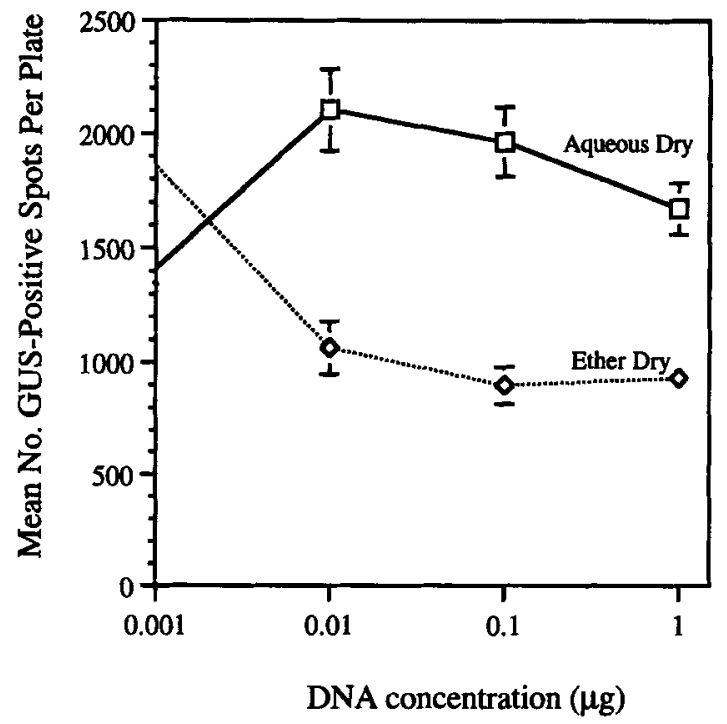

Fig. 2. Effect of carrier DNA. Purified pUC118 at different concentrations was complexed to $M-10$ particles before being mixed with bacteria. Aqueous-dried bacteria were used to bombard maize BMS cells. whereas ether-dried bacteria were used to bombard tobacco NTl cells, and thus should not be directly compared.

placed on the macrocarrier also had a strong effect on transformation (Fig. 5). Although the heaviest loads yielded the highest rates of transient gene expression, there were significant deposits of tungsten on the bombarded plates. Tungsten is toxic to some cells (Russell et al., 1992) and may reduce stable transformation rates.

Three parameters had a negative effect on DNA delivery when ether-dried bacteria were used. Firstly, when earrier DNA ( $\mathrm{U} U \mathrm{C} 118$ ) 

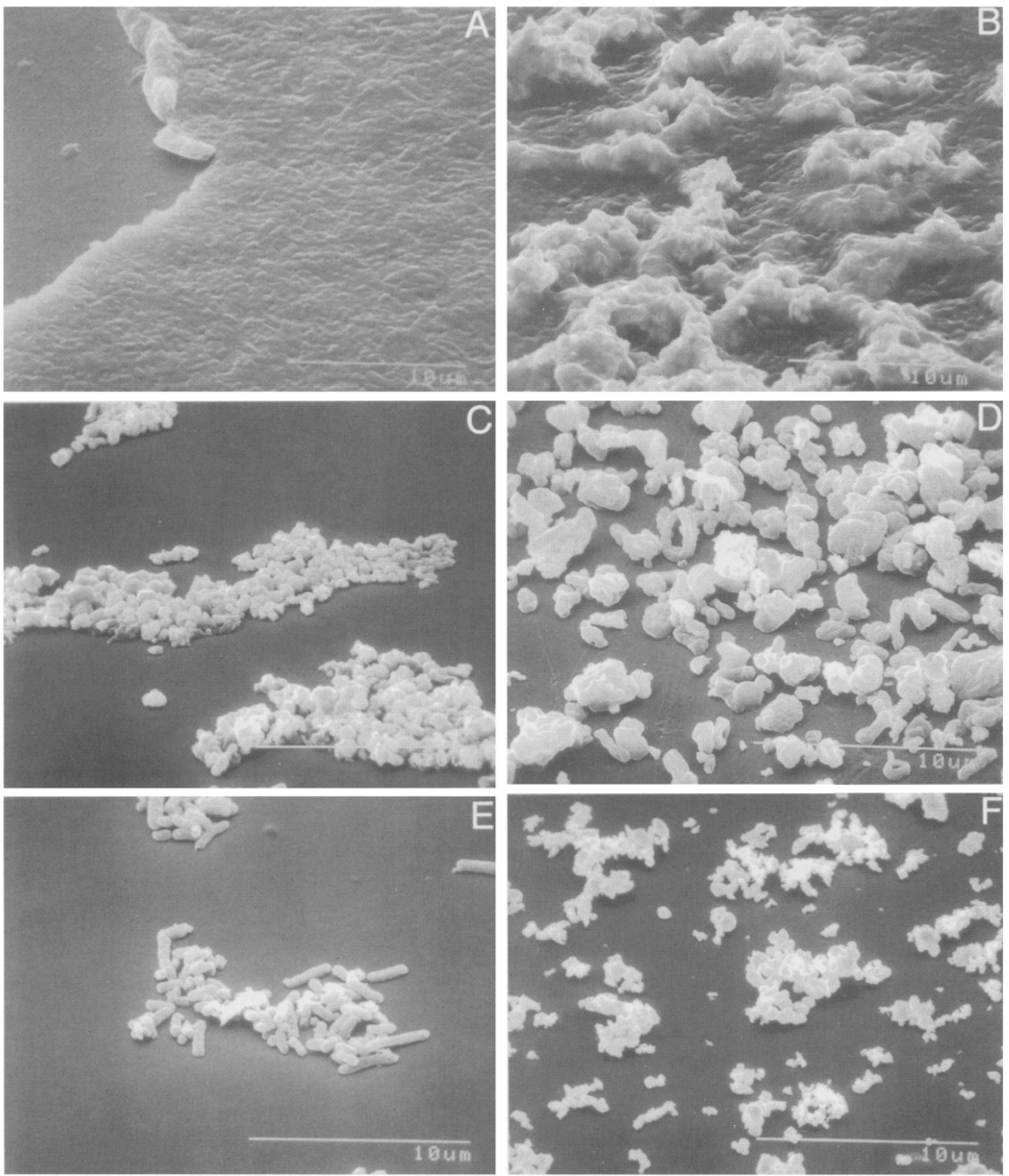

FIG. 3. Scanning electron mierographs of macrocarriers that contain different particle preparations: $A$, Aqueous-dried bacteria without tungsten, $B$, Aqueous-dried bacteria with tungsten, $C$, Ether-dried bacteria with tungsten, $D$, Spray-dried bacteria with tungsten, $E$, Goldplated bacteria, $F, \mathrm{CsCl}$ purified DNA complexed to $\mathrm{M}-10$ tungsten particles. Bar is $10 \mu \mathrm{m}$. 


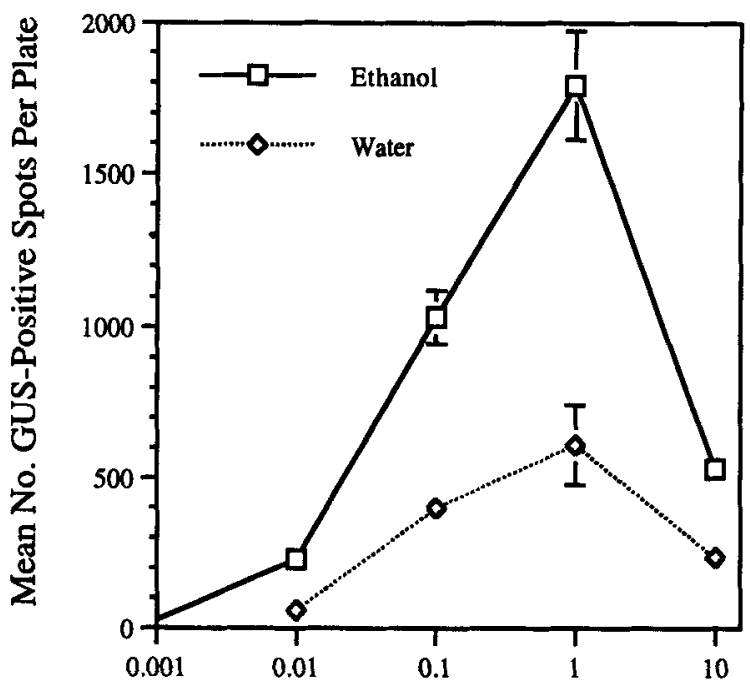

mg Tungsten per ml Bacteria

FIG. 4. Effect of tungsten concentration in the ether-dry preparation and the solution (100\% EtOH or water) used to resuspend the powder before loading on the macrocarriers. The particles were used to bombard tobacco NTl cells.

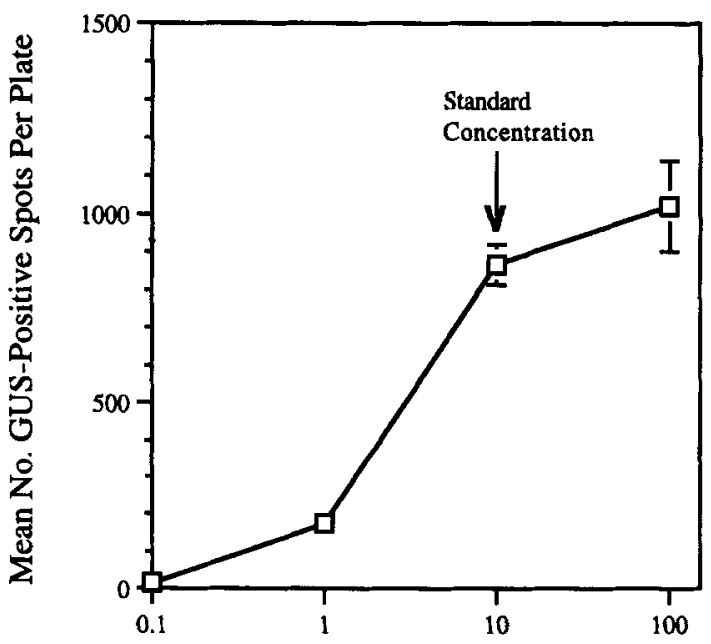

mg of Bacteria/M-10 Powder

FIG. 5. Effect of the quantity of bacteria/M-10 ether-dried powder loaded onto the macrocarrier. Values are milligrams of powder that was resuspended in $150 \mu \mathrm{l}$ of absolute ethanol. A $6-\mu \mathrm{l}$ aliquot of the suspension was loaded onto each macrocarrier. The particles were used to bombard tobacco NTI cells.

was complexed to the tungsten particles before mixing with the bacteria, the number of blue spots observed from bombarded tobacco cells was reduced (Fig. 2). As discussed earlier, the opposite effect was observed with aqueous-dried bacteria. Secondly, a helium flush of the chamber before bombardment reduced the number of blue spots per plate in tobacco from 1345 without helium to 1030 with helium flush $(P=0.02)$. Thirdly, when polycationic polymers, re-
TABLE 3

COMPARISON OF PURIFIED PLASMID WITH AQUEOUS-DRIED OR ETHER-DRIED E. COLI/TUNGSTEN PROJECTILES FOR TRANSFORMATION OF MAIZE AND TOBACCO CELLS

\begin{tabular}{|c|c|c|c|c|}
\hline \multirow[b]{2}{*}{ Projectile } & \multicolumn{2}{|c|}{ Maize BMS cells ${ }^{\mathrm{a}}$} & \multicolumn{2}{|c|}{ Tobacco NTl cells ${ }^{*}$} \\
\hline & $\begin{array}{l}\text { No. Gus- } \\
\text { positive spots }\end{array}$ & No. PPT calli & $\begin{array}{l}\text { No. GUS- } \\
\text { positive spots }\end{array}$ & No. $\mathrm{Km}^{\mathrm{r}}$ call \\
\hline pUCI18 & $0 \mathrm{z}$ & $0 \mathrm{z}$ & $0 z$ & $0 \mathrm{z}$ \\
\hline pBI426 & NT & NT & $8523 y$ & $439 y$ \\
\hline pSAN18 & $4141 \times$ & $78 x$ & $\mathrm{NT}$ & NT \\
\hline $\begin{array}{l}E . \text { coli }+ \text { plasmid } \\
\text { Aqueous-dry }\end{array}$ & $1923 \mathrm{y}$ & $47 y$ & $27 z$ & $\mathrm{O}_{\mathrm{z}}$ \\
\hline Ether-dry & $1348 y$ & $28 \mathrm{y}$ & $349_{z}$ & $2 z$ \\
\hline E. $\operatorname{coli}(-)$ plasmid & $0 \mathrm{z}$ & $0 \mathrm{z}$ & NT & $\mathrm{NT}$ \\
\hline
\end{tabular}

"Values represent the mean of two experiments with maize and four experiments with tobacco (20 to 25 plates per treatment). Means within each column that are followed by the same letter are not significantly different as determined by a least significant difference test at the $5 \%$ level. NT means not tested.

ported to promote bacterial adhesion to hydrocarbon and polystyrene surfaces (Goldberg et al., 1990), were used, the bacterial suspensions were sticky and difficult to handle. Chitosan reduced transformation approximately $50 \%$ ( 417 blue spots vs. 984 without chitosan; $P=$ 0.02 ). Similarly, the number of GUS-expressing cells was lower with poly-L-lysine (852) and lysozyme (594)-treated bacteria than with nontreated bacteria (1238), $P=0.14$ and $P=0.01$, respectively.

Ether-dried bacteria were compared with both aqueous-dried bacteria and purified DNA for DNA delivery into tobacco and maize cells (Table 3). In maize, both bacterial preparations gave high rates of transient gene expression and recovery of PPT ${ }^{r}$ colonies, and the rate was only roughly twofold lower than when purified DNA was used. In tobacco, the number of GUS-expressing cells and $\mathrm{Km}^{\mathrm{r}}$ calli was higher with ether-dried bacteria than with aqueous-dried bacteria, but this was not statistically significant in a multiple comparisons test when isolated plasmid was included. Purified DNA yielded significantly higher numbers of GUS-positive sectors and $\mathrm{Km}^{\mathrm{r}}$ or PPT ${ }^{\mathrm{r}}$ calli in both maize and tobacco.

Other methods. Transient GUS expression was not observed when spray-dried (Fig. $3 d$ ) or gold-plated (Fig. $3 e$ ) bacteria were used to bombard maize cells. Similarly, bacteria prepared by the $37^{\circ} \mathrm{C}$-dry method yielded an average of only 0.2 blue spots per plate. Gold sputter-coated bacteria yielded less than 5 GUS-positive cell clusters per plate.

Other plant species. Transient gene expression was evaluated in petunia and rice cell suspensions after bombardment with aqueousdry bacteria. The difference in numbers of GUS-positive sectors between purified pBI426 (1853) and E. coli projectiles (209) was ninefold in petunia $(P=0.00)$. In rice, purified pBI426 yielded 6412 blue spots per plate vs. 2030 with $E$. coli projectiles, a threefold difference $(P=0.00)$. With petunia leaves there were 437 blue spots per plate with aqueous-dried bacteria vs. 3 per plate with ether-dried bacteria $(P=0.02$ ). The number of blue spots could not be counted on the leaves bombarded with purified pBI426 because they were too numerous and convergent, making it difficult to distinguish individual hits. No stable transformants grew from any of the petunia leaf transformations (purified plasmid or bacteria). 


\section{DISCUSSION}

Biological projectiles eliminate the need to isolate and purify DNA for the biolistic delivery process, which saves time and lessens DNA shear. Furthermore, they may circumvent some of the other problems inherent in the use of metal particles (discussed by Rasmussen et al., 1994). Given efficient rates of transformation with biological particles, they may be useful in delivery of high molecular weight DNA such as bacteriophage genomes, yeast artificial chromosomes, or bacterial artificial chromosomes. Once a high molecular weight construct is made and transformed into the appropriate microorganism, it need not be further isolated or purified. Although Rasmussen et al. (1994) reported initial success with bacterial projectiles, data on stable transformation was limited. Phage particles and yeast cells offer some intriguing possibilities for plant transformation, but had not previously been tested.

Bacteriophage lambda particles have an icosahedral head $0.05 \mu \mathrm{m}$ in diameter, with a tubular tail $0.15 \mu \mathrm{m}$ long (Hershey and Dove, 1983). Because phage particles are small, they could readily penetrate plant cells without doing significant damage, if they could achieve the velocity needed. Attachment to tungsten or gold particles would seem to be the ideal mechanism to confer upon the phage enough density and momentum. Lambda phage particles were previously used in our laboratory to transform yeast cells. The highest numbers of transformants were obtained when the phage were complexed with tungsten particles, and carrier DNA was used in the reaction mixture (Rasmussen and Sanford, unpublished results). The plaque assays in this study indicate that with the right conditions, at least half of the phage are associated with the tungsten particles. It is possible that DNA delivery to plants was so poor because the phage were not tightly bound to the tungsten and came off the particles in flight or upon impact with the plant cells. Alternatively, the chemical environment of plant cytoplasm may not be conducive to release of DNA from the phage particles, or there may be some hypersensitive-like response of plant cells to the phage, resulting in death.

Yeast cells in their natural state are probably too large to be effective projectiles for plant targets. Metal particles used for biolistic transformation of plants are typically $1 \mu \mathrm{m}$ in diameter. Larger 2.4 $\mu \mathrm{m}$ tungsten particles are less effective for plant cell transformation (Klein et al., 1988a, 1988b), but the optimum size depends on the size of the target cells. Wild type yeast cells are spheroid and approximately $6 \mu \mathrm{m}$ in diameter. Dehydration treatments probably did not shrink the cells more than $50 \%$. Even mutant 'Wee' yeast $(3 \mu \mathrm{m}$ in diameter) (Sudbery et al., 1980; Tyers et al., 1992) may be too large, especially when complexed with tungsten. Spores or yeast nuclei are smaller potential projectiles, but these were not tested in this study. Ito et al. (1983) reported that treatment of yeast cells with alkali cations improved uptake of plasmid DNA from the surrounding medium. We tested $\mathrm{LiCl}$ and other chemical treatments for their potential to improve release of DNA from yeast cells which might be limiting, but such treatments did not improve transformation rates.

Rod-shaped $E$. coli cells, approximately $0.5 \mu \mathrm{m}$ wide and $1-3 \mu \mathrm{m}$ long, are a more reasonable projectile size compared to yeast, especially if the narrow end penetrates the plant cells first. However, the size of the bacteria/tungsten complex still may be larger than desired. The dehydration methods (ether-dry, spray-dry, $37^{\circ} \mathrm{C}$-dry) were expected to shrink the cells into small spheroids. Scanning electron microscopy (SEM) revealed that the cells remained rod shaped and roughly $1 \mu \mathrm{m}$ long. $E$. coli mini-cells (Clark-Curtiss and Curtiss III, 1983), 1/10 the size of regular cells, might be useful for plant transformation but were not tested in this study.

Aqueous-dried bacteria, prepared as described by Rasmussen et al. (1994), yielded high rates of transient GUS expression and PPT calli in maize cells when the bacteria contained a strongly-expressed plasmid. SEM revealed that aqueous-dried bacteria are laid down in a thick "mat" on the macrocarrier. This seemed less than optimal, but because rates of transformation are good, the "mat" must be able to break up and carry the tungsten/bacteria complex into the plant cells. Perhaps the "mat" is needed for the tungsten and bacteria to bind together effectively. Precoating the tungsten particles with carrier DNA improved DNA delivery in aqueous-dried cells, possibly making the bacteria better able to bind to the tungsten. Additionally, $E$. coli have many pili on their cell surface (Ingraham et al., 1983) that may help the bacteria adhere to the tungsten particles.

Ether-dried bacteria and aqueous-dried bacteria yielded equally high rates of transformation in maize cells. The aqueous-dry method is preferred because the extra washes of the ether-dry procedure take additional time. However, in tobacco, ether-dried bacteria yielded higher rates of transient CUS expression and even a few $\mathrm{Km}^{r}$ calli per plate. In contrast, nurnerous bombardments of tobacco with aqueous-dried bacteria yielded no $\mathrm{Km}^{\mathrm{r}}$ calli. The extra washes of the ether-dry procedure may eliminate some component that causes a deleterious or hypersensitive response in tobacco. On the other hand, the ethanol washes may have interfered with our attempts to improve binding to tungsten via carrier DNA or polycationic polymers.

Other methods to prepare bacterial projectiles for plant transformation were completely ineffective. Spray-drying and $37^{\circ} \mathrm{C}$-drying failed to shrink the cells as hoped, and no GUS-expressing cells were obtained. The extra drying may have damaged the cells or somehow inhibited DNA release. Gold electroplating was used to make the cells more dense, but the thin layer of gold added may not have contributed significantly to the cell mass. Additionally, the gold coating may have interfered with DNA release from the cells. Gold sputter-coating may have caused similar problems, and in this case release of bacteria from the macrocarrier was in sheets instead of individual particles.

In summary, phage and yeast projectiles were only marginally effective for plant transformation and appeared impractical. Phage still has potential because of its small size. However, better methods to bind phage with metal particles would be needed. $E$. coli, on the other hand, are effective projectiles when complexed with tungsten. Transformation rates in maize were only two- to threefold lower than with purified DNA. Rates in tobacco were much lower, but stable transformants could be recovered with the ether-dry method described in this report. The frequency of transient gene expression was also good in rice and petunia cell suspensions that were bombarded with aqueous-dried bacteria. Bacterial projectiles were also able to penetrate and express within intaet petunia leaves. Although biological projectiles are not expected to replace standard preparations of purified DNA complexed to tungsten or gold (unless transformation rates are further improved) for biolistic plant transformation, they may have some utility wherever DNA isolation is difficult or problematic.

\section{ACKNOWLEDGMENTS}

We gratefully acknowledge the following individuals for supplying DNA, microbial strains, and/or plant cells used in this project: Alan Blowers, Bill 
Crosby, Jun Cao, Michael Fromm, Bruce Futcher, David McElroy, Jeanette Rasmussen, Rody Spivey, and Joyce VanEck. We also thank Scott Hawkes and Joe Davidson for assistance with spray-drying and to Brian Terhune for help with sputter-coating and SEM. This research was supported in part by USDA/NRICGP grant no. 93-37300-8777.

\section{REFERENCES}

Amin, M. K.; Day, M. J. Influence of $\mathrm{pH}$ value on viability and transduction frequency of Pseudomonas aeruginosa phage F116. Lett. Appl. Microbiol. 6:93-96; 1988.

Armaleo, D.; Ye, G. N.; Klein, T. M.; Shark, K. B.; Sanford, J. C.; Johnston, S. A. Biolistic nuclear transformation of Saccharomyces cerevisiae and other fungi. Curr. Genet. 17:97-103; 1990.

Cao, J.; Zhang, W.; McElroy, D.; Wu, R. Assessment of rice genetic transformation techniques. In: Khush, G. S.; Toenniessen, G. H., ed. Rice biotechnology. Wallingford, U.K.: C.A.B. International; 1991:175198.

Clark-Curtiss, J. E.; Curtiss III, R. Analysis of recombinant DNA using Escherichia coli minicells. Methods Enzymol. 101:347-363; 1983.

Fromm, M. E.; Callis, J.; Taylor, L. P.., Walbot, V. Electroporation of DNA and RNA into plant protoplasts. Methods Enzymol. 153:351-366; 1987.

Fromm, M. E.; Morrish, F.; Armstrong, C.; Williams, R.; Thomas, J.; Klein, T. M. Inheritance and expression of chimeric genes in the progeny of transgenic maize plants. Bio/Technology 8:833-839; 1990.

Goluberg. S.; Doyle, R. J.; Rusenberg, M. Mechanism of enhancement of microbial cell hydrophobicity by cationic polymers. J. Bacteriol. 172:5650-5654: 1990.

Han, J. H.; Rutter, W. J. $\lambda \mathrm{gt} 22$, an improved $\lambda$ vector for the directional cloning of full-length cDNA. Nucleic Acids Res. 15:6304: 1987.

Hershey, A. D.: Dove. W. Introduction to lambda, In: Hendrix, R. W., et al., ed. Lambda II. Cold Spring Harbor. NY: Cold Spring Harbor Laboratory Press; 1983:3-11

Hill. J. E.: Myers, A. M.; Koerner, T. J.; Tzagoloff, A. Yeast/E, coli shuttle vectors with multiple unique restriction sites. Yeast 2:163-167; 1986.

Ingraham, J. L.; Maaløe, O.: Neidhardt, F. C. Growth of the bacterial cell. Sunderland. MA: Sinauer Associates, Inc.; 1983:36.

Ito, H.; Fukuda, Y.; Murata, K.; Kimura, A. Transformation of intact yeast cells treated with alkali cations. J. Bacteriol 153:163-168; 1983.
Kikkert, J. R. The Biolistic $®$ PDS-1000/He device. Plant Cell Tissue Organ Cult. 33:221-226; 1993.

Klein, T. M.: Fromm, M. E.; Weissinger, A.; Tomes, D.; Schaff, S.; Sletten, M.; Sanford, J. C. Transfer of foreign genes into intact maize cells with high-velocity microprojectiles. Proc. Natl. Acad. Sci. USA 85:4305-4309; 1988a.

Klein, T. M.; Gradziel, T.; Fromm, M. E.; Sanford, J. C. Factors influencing gene delivery into Zea mays cells by high-velocity microprojectiles. Bio/Technology 6:559-563; 1988b.

Klein, T. M.; Knowlton, S.; Arentzen, R. Gene transfer by particle bombardment. In: Lindsey, K., ed. Plant tissue culture manual. Dordrecht. The Netherlands: Kluwer Academic Publishers; 1991:1-12.

McCabe, D. E.; Swain, W. F.; Martinell. B. J.: Christou, P. Stable transformation of soybean (Glycine max) by particle acceleration. Bio/Technology 6:923-926; 1988.

Pruitt, K. D.; Hanson, M. R. Transcription of the Petunia mitochondrial CMSassociated Pcf locus in male sterile and fertility-restored lines. Mol. Gen. Genet. 227:348-355; 1991.

Rasmussen, J. L.; Kikkert, J. R.; Roy, M. K.: Sanford, J. C. Biolistic transformation of tobacco and maize suspension cells using bacterial cells as microprojectiles. Plant Cell Rep. 13:212-217; 1994.

Russell, J. A.; Roy, M. K.; Sanford, J. C. Major improvements in biolistic transformation of suspension-cultured tobacco cells. In Vitro Cell. Dev. Biol. 28P:97-105; 1992.

Sambrook, J.; Fritsch, E. F.; Maniatis, T. Molecular cloning; a laboratory manual, 2nd ed. Cold Spring Harbor, NY: Cold Spring Harbor Laboratory Press: 1989:2.60-2.81.

Sanford, J. C.; DeVit, M. J.; Russell, J. A.; Smith, F. D.; Harpending, P. R.; Roy, M. K.; Johnston, S. A. An improved, helium-driven biolistic device. Technique 3:3-16; 1991.

Sanford, J. C.: Smith, F. D.; Russell, J. A. Optimizing the biolistic process for different biological applications. Methods Enzymol, 217:483-509; 1993.

Sudbery, P. E.: Goodey, A. R.; Carter, B. L. A. Genes which control cell proliferation in the yeast Saccharomyces cerevisiae. Nature (Lond.) 288:401-404; 1980 .

Tyers, M.; Tokiwa, G.; Nash, R.; Futcher, B. The $\mathrm{Cln} 3-\mathrm{Cdc} 28$ kinase complex of $S$. cerevisiae is regulated by proteolysis and phosphorylation. EMBO J. 11:1773-1784; 1992.

Vieira, J.; Messing, J. Production of single-stranded plasmid DNA. Methods Enzymol. 153:3-11: 1987. 